April 2012

\title{
On Situating the Study of Genocide within Political Violence
}

Ernesto Verdeja

Follow this and additional works at: https://digitalcommons.usf.edu/gsp

\section{Recommended Citation}

Verdeja, Ernesto (2012) "On Situating the Study of Genocide within Political Violence," Genocide Studies and Prevention: An International Journal: Vol. 7: Iss. 1: Article 9.

Available at: https://digitalcommons.usf.edu/gsp/vol7/iss1/9

This Articles is brought to you for free and open access by the Open Access Journals at Digital Commons @ University of South Florida. It has been accepted for inclusion in Genocide Studies and Prevention: An International Journal by an authorized editor of Digital Commons @ University of South Florida. For more information, please contact digitalcommons@usf.edu. 


\title{
On Situating the Study of Genocide within Political Violence ${ }^{1}$
}

\author{
Ernesto Verdeja \\ University of Notre Dame
}

This article identifies a particular challenge for comparative genocide studies, namely the underemphasis of investigation into the relationship between genocide and other forms of political violence and the ways in which they are related temporally and spatially. It advocates situating genocide studies within the broader domain of political violence research to explain not only the causes of genocide but general variation in violent outcomes. By systematically comparing genocides to nongenocides, we gain greater insights into the factors that result in large-scale, group-oriented destruction. The article also calls for greater disaggregation of analytical frameworks in comparative research, including the adoption of microanalytical perspectives to explain variation in the onset, dynamics, and abeyance of violence within cases.

Key words: comparative genocide, causes of genocide, microanalysis, methodology

The past twenty years have seen impressive advances in the comparative study of the causes and patterns of genocide. Following World War II, most analyses of genocide focused on the Holocaust. These earlier works presented us with sophisticated understandings of the historical, ideological, and structural origins of anti-Semitism, Nazi policies, and the dynamics of mass violence that resulted in the genocide of Europe's Jewish and Roma and Sinti populations. ${ }^{2}$ In the years following 1945, however, there were few comparative studies of genocide, and most of those were largely ignored by social scientists.

Beginning with a number of pioneering works in the 1980s, and continuing through the 1990s with the violence in Rwanda and the former Yugoslavia, scholars turned their attention to the methods of comparative assessment. This "second generation" of comparative work continues to produce important insights into the conditions, onset, and patterns of genocide. ${ }^{3}$ Scholars have widened their interests to explore the relationships of imperialism and colonialism with modern genocide as well as the connections linking environmental degradation and resource scarcity to mass killing. ${ }^{4}$ Some have called for a reinterpretation of Cold War state terror through the rubric of genocide. ${ }^{5}$ And still other analysts are calling for a fundamental reframing of our basic epistemological and ontological assumptions about genocide, drawing on critical theory, post-structuralism, and other areas of political theory with provocative and important results. The interdisciplinary field of genocide studies is growing and becoming more analytically sophisticated. ${ }^{6}$

Nevertheless, the field faces some basic questions and challenges, including definitional disagreements that affect the scope and types of cases chosen; problematic understandings of intentionality; and reductive conceptualizations of ideology and rationality, among other issues. ${ }^{7}$ Given space constraints, here I focus on one specific 
issue requiring further attention: the relationship between genocide and other kinds of political violence. How is genocide related temporally (in terms of sequencing) and spatially to other kinds of violence? Although we have increasingly rich and sophisticated empirical accounts of specific cases of genocide, our understanding of the theoretical relationships between genocide and violence more generally is still under-developed. This is especially evident in comparative causal theories, which focus largely on the comparison of genocides and thus ignore connections between genocide and variations of extreme violence, such as revolution, civil war, counterinsurgency strategy, and the like.

This article does not provide an overview of the field of comparative genocide studies. ${ }^{8}$ Instead, I examine the theoretical challenge of articulating genocide's relationship to political violence and sketch a few ways forward for the field. These comments are motivated by the belief that we should seek not only to understand the historical contingencies of genocide in particular cases but also to develop theoretical knowledge of mass political violence: the conditions under which it is likely to occur, the small-scale processes (or, in Charles Tilly's terms, "mechanisms") of violent escalation and deescalation at local levels, and the ways in which these processes are shaped by, connect to, reinforce, accelerate, and impede higher-level processes of violence. ${ }^{9}$ We should explain, in other words, variability in violent outcomes. With a few exceptions, our comparative theories have yet to develop systematic theoretical accounts for the interactions of these various levels of violence (micro, meso, macro) and consequently the onset and diffusion of genocidal violence; nor do they investigate cases where genocide did not occur.

The points below are primarily aimed at comparative works on the causes of genocide-a topic that continues to receive an enormous amount of attention from scholars. The comments are largely methodological in nature and are thus a few degrees removed from the deeper epistemological and ontological debates currently raging in our field. Nevertheless, these methodological issues require attention if our knowledge of this terrible phenomenon is to deepen.

\section{Genocide and Political Violence}

It is by now well established that genocide and war often go hand in hand. Numerous studies have shown that genocides tend to occur during wars, when populations are living under conditions of fear and are de-sensitized to the use of mass violence, when ingroup and out-group distinctions are pronounced, when the elite are likely to choose more radical strategies to achieve their aims, and when state resources are already mobilized for the killing of enemies and the repression of internal dissent. ${ }^{10}$ Nevertheless, comparative research on the causes of genocide has generally been remarkably uninterested in exploring how genocide is situated in the wider constellation of political violence. Instead, studies have largely focused on cases in which the outcome has been genocide. To be clear, I am not arguing that scholars have failed to explore antecedent factors or that they have only studied specific genocidal periods (say Armenia 19151923, Cambodia 1975-1979, etc.). Indeed, most of the comparative literature in the field draws on a wide variety of background conditions to explain genocide, from historical and structural factors (state formation, regime types, political culture, histories of exclusion going back decades or more, and the like) to more immediate factors, such as political crises and the strategic choices of the elite. Rather, the problem has been that cases 
are chosen for analysis based on the experience of genocide, while other instances with similar prior conditions and different violent outcomes are mostly ignored.

The narrow focus of research on cases of genocide (or selection on the dependent variable) carries some significant methodological problems. By studying only those cases which have resulted in genocide, how do we know whether our proposed factors, causal dynamics, and processes actually explain genocide? It may be that these same factors explain other forms of violence as well and that we are consequently misidentifying the true fundamental and distinct causes of genocide. The problem is that in studying only genocides we likely choose only those cases that confirm our theoretical assumptions at the expense of discovering whether our stipulated causal mechanisms are indeed primary causal factors. Take, for instance, the examination of only highly ideological genocides. Bounded in this way, one's findings are likely to show that radical ideologies are a primary cause of genocide (which itself risks being tautological), while failing to explain how these ideologies may be present in less violent outcomes or not present in other cases sharing many of the empirical features of genocide. ${ }^{11}$ If radical ideologies also appear in non-genocidal violence, then we need to re-examine the causal importance of ideology to genocide. And yet without investigating cases with broadly similar prior conditions but different violent outcomes, it is difficult to gauge the importance of ideology (or any other factor).

There are several possible ways forward. First, scholars should broaden the types of violence they study and thus situate genocide more thoroughly within the literature of political violence. Rather than ask, "What do all genocides have in common?" (a question, incidentally, made all the more difficult given the lack of consensus in the field on the definition of genocide ${ }^{12}$ ), we should explore the conditions that lead to extreme forms of political violence- of which genocide is a subset-as well as examine the ways in which genocide and other forms of political violence interact and reinforce one another. To do this, the field needs to engage with advances in other research areas on political violence, such as civil war and non-genocidal state repression. Second, comparative genocide scholars should look to the expanding microanalysis work on violence (such as research on civil wars) as a way of better understanding the dissemination, intensity, and patterns of violence within cases. In sum, the comparative study of genocide needs to engage the broader domain of conflict studies.

\section{Genocide and Political Violence: Expanding the Research Frame}

I am advocating a change in theoretical perspective to situate genocide within the larger context of political violence instead of focusing solely on the study of genocide. I do not claim that we should abandon single-case or comparative studies of genocide tout court, since these methods have developed important theoretical and practical knowledge. Rather, I envision this contextual turn (and broadening) as a complement to the "genocide only" approaches still dominating our field. This alternative contextual approach has, I believe, several benefits: it would draw attention to the broader host of perpetrator repressive and destructive policies (beyond those leading to genocide), show the interactive effects and general processes of perpetrator policy radicalization, and shed light on the different steps in the continuum of repression. In addition, by extending our research to cover instances of non-genocidal mass violence we could explore why genocide does not occur in certain cases and why, in other scenarios, violence might remain constant, without degenerating into intentional extermination. Extant comparative literature in genocide studies does not adequately account for either possibility. ${ }^{13}$ 
Without wider research into cases of political violence we risk producing causal theories that either misrepresent the causes of genocide or over-determine outcomes. In other words, we cannot understand why political violence escalates, remains constant, or declines.

The state repression literature may be helpful here. ${ }^{14}$ Scholars across disciplines have explored when and how repressive behavior increases and decreases. ${ }^{15}$ The questions that arise from these lines of inquiry are widely varied, but they are meant to encapsulate a broad range of violent behavior beyond genocide alone. For instance, researchers ask, Under what conditions do states move from institutional coercive practices, such as legalized civil and political discrimination or language restrictions, to wider forms of collective suppression, such as total language and religious prohibitions? When do occasional riots turn into sustained attacks and when do they not? Why do targeted forced displacements become large-scale, violent deportations in some cases and not in others? And why do some states settle on forced conversion or the removal of target populations, while others choose extermination? The state repression literature includes a variety of methodological approaches, but it generally shares a commitment to exploring the emergence, sustainment, decline, and variation of repression and violence in a multiplicity of forms and over time. ${ }^{16}$ In addition, much of the best repression literature is interactive in approach ${ }^{17}$; it investigates how interactions between the state and non-state actors (armed and unarmed) alter the political landscape, in some cases escalating violence and in others lessening the probability of conflict. Contextualizing genocide research within the broader domain of political violence can provide us with theoretical purchase on change and variability in violent outcomes. With some important exceptions, works in our field fail to draw general theoretical insights about radicalization from case-specific historical contingencies. ${ }^{18}$ Given that so little comparative genocide research embeds its analytical framework within broader explanatory models of political violence, it is perhaps unsurprising that genocide seems over-determined: the frameworks provide few theoretical resources for understanding the escalation and de-escalation of violence. Anchoring our causal theories within the political violence literature may allow us to theorize more broadly about the dynamics of escalation and de-escalation.

\section{Microanalysis of Genocide}

We should also pursue more microanalyses to explain the dissemination and intensity of violence within cases (a point relevant to genocide studies and the study of political violence more generally). Country-level studies are still prevalent in comparative genocide research. Vahakn Dadrian, Leo Kuper, and Richard Hovannisian produced classic works focusing on the role of pre-existing cleavages in society, and Irving L. Horowitz, Rudolph Rummel, and Hannah Arendt drew attention to regime type and state power to explain genocide. ${ }^{19}$ More recently, Barbara Harff has analyzed the destabilizing effects of national political crises and Benjamin Valentino has focused on the interests and goals of national elites. ${ }^{20}$ Michael Mann has traced the process of elite and follower radicalization against a background of utopic ideologies and the rise of modern mass democracy. ${ }^{21}$ Nevertheless, outside of anthropological and historical studies, ${ }^{22}$ there is still relatively little work that systematically explains internal differences across space and time. Genocide is understood as an aggregate outcome of country-level factors, while variation within states and regions is ignored. This can lead to an overrepresentation of the role of national elites and macro-level state failure and the employment of 
static and reified conceptions like "masses" and "ethnicity" at the expense of understanding sub-national and local dynamics and patterns of violence (and non-violence).

We should complement and deepen these macro-level studies by investigating spatial and temporal variations within case studies (countries or regions, such as the Great Lakes region). Doing so could provide us with a better understanding of why genocidal violence occurs in some places prior to others, and what the micro- or meso-causal processes that affect internal variation might be. Current research on civil war has taken this microanalytical turn and made important findings. The field of genocide studies could draw from these methodological advances to great effect. ${ }^{23}$

A host of questions are open to microanalytic research on genocide, such as: (1) How is identity articulated and acted upon in particular circumstances? We know from careful ethnographic research that master ideological narratives articulated by elites (ethnic, political, regional, religious, or other) frequently have complex and rather indirect relations to violence in situ. ${ }^{24}$ Skin color, height, or facial features may operate as reductive phenotypal indicators in official discourse, but they might also be interpreted in a variety of ways depending on local attitudes. Accent or linguistic competence may serve as a relevant signifier in other instances, but here, too, perpetrators often interpret identity in myriad ways. More tangential markers, such as clothing, occupation, or neighborhood of residence may function as proxies for primary identity. And of course, when victim groups are displaced and fleeing, interpretations may become looser and more encompassing to ensure that no potential "enemies" escape. (2) What is the role of geography in the onset and diffusion of violence? Geography plays an important role in our understanding of the Armenian resistance in Musa Dagh, and, elsewhere, in the abilities of Tutsi and Hutu to evade murder and the Khmer Rouge's unstable control over various national zones. Yet we still have no sophisticated explanation for the role of geography in genocide as such. ${ }^{25}$ Finally, (3) consider state power (or capacity), frequently put forth as central to explaining genocide. Rudolph Rummel noted crisply, "Power kills; absolute power kills absolutely." 26 However, measuring state power at the national level—as Rummel does-provides little insight into when genocide is likely to occur or how it may spread. ${ }^{27}$ States may have uneven control over their territory given coercive and intelligence gathering capacities, which may explain why in some places violence is highly targeted, while in others it is wild and all-encompassing. Greater sensitivity to state coercive capacity across space and time, as well as the use of local allies and proxies, could provide us with more nuanced understandings of repression and mass killings.

Of course, some genocide scholars are already moving in this direction with sophisticated ideographic studies on the Ottoman Empire, Cambodia, and Rwanda. ${ }^{28}$ However, comparative research has not integrated their methodological perspectives. Studies on the Holocaust are furthest along in this area-unsurprising given the attention it has received for 60 years-but we need more of this type of analysis to enrich our comparative theories. Particularly in the context of war, in which genocide is most likely to occur, violence is multidirectional and includes a host of armed and unarmed actors, with variations in level, organization, and types of violence across space and time. ${ }^{29} \mathrm{We}$ need a better theoretical understanding of these dynamics.

Micro-level analysis strengthens comparative research in at least three ways. First, as Scott Straus has noted, it increases the number of observations available for study, allowing for more nuanced understandings of violent dynamics than those found in 
macro-level studies. ${ }^{30}$ Second, it de-centers our general descriptions of violent phenomena. Greater sensitivity to local variation forces scholars to rethink how master narratives may (or may not) connect to local violence and thus problematizes analytical categorizations such as race and ethnicity. Finally, a microanalytical approach challenges the standard beginnings and endpoints of violent phenomena, such as genocide, and instead highlights the continuity and discontinuity of violence before and after event-defining dates, thereby avoiding their arbitrary (and often rather neat) truncation.

Clearly, there are challenges to employing micro-level analyses. Genocide requires elite commitment, complex logistical coordination, and the work of specialized killers; it does not erupt spontaneously and randomly in communities, but is instead rooted in broader political, institutional, and social contexts. Macro comparative frameworks help us assess whether (and how) particular dynamics of violence fit wider patterns and to what extent we can generalize across cases. But the point here is not to replace higher-level analysis with microanalysis. Rather, micro approaches can complement macroanalyses by providing us with more nuanced accounts of the onset and patterns of genocide, consequently forcing us to rethink our broader analytical frameworks. A clearer understanding of local processes and circumstances, and the way in which these interact with meso- and macro-scale phenomena, could help us avoid generalizing causal theories that ignore real and important local differences. ${ }^{31}$

\section{Conclusion}

This article has identified a particular problem for genocide studies, namely the underemphasis of systematic investigation into the relation between genocide and other forms of political violence, and the ways in which they are related temporally (in terms of sequencing) and spatially. There is not necessarily one way to fill this research need, and the use of state repression literature in political science and sociology introduced here is only one possible way forward. Contemporary microanalytical advances in the civil war literature can also serve as an illustration of how to disaggregate analyses in such a way that more general theoretical insights can continue to be generated. Clearly, the field of genocide studies is both inter- and multidisciplinary, and it would be shortsighted to advocate for a single methodological answer to the problems raised here. Nevertheless, scholars need to engage these problems if we are to advance our understanding of these dimensions of genocide.

Ernesto Verdeja is Assistant Professor of Political Science and Peace Studies, University of Notre Dame. $\mathrm{He}$ is the author of Unchopping A Tree: Reconciliation in the Aftermath of Political Violence and serves on the boards of the Institute for the Study of Genocide and the International Association of Genocide Scholars.

\section{Notes}

1. Special thanks to Christian Davenport, Henry Theriault, and Samuel Totten for their comments on the issues raised in this article.

2. Raul Hilberg, The Destruction of the European Jews, 3 vols (London: W. H. Allen, 1961); Lucy Dawidowicz, The War Against The Jews, 1933-1945 (New York: Holt, Rinehart and Winston, 1975); Léon Poliakov, Harvest of Hate: The Nazi Program for the Destruction of Jews in Europe (New York: History Library, 1956).

3. Scott Straus, "Second Generation Comparative Research on Genocide," World Politics 59 (2007): 476501; Ernesto Verdeja, "Genocide: Clarifying Concepts and Causes of Cruelty," Review of Politics 72 (2010): 513-26.

4. A. Dirk Moses, ed., Empire, Colony, Genocide: Conquest, Occupation and Subaltern Resistance in World History (London: Berghahn Books, 2008); Nicholas Robins and Adam Jones, Genocides by the 
Oppressed: Subaltern Genocide in Theory and Practice (Bloomington, IN: Indiana UP, 2009); Mark Levene, "From Past to Future: Prospects for Genocide and its Avoidance in the Twenty-First Century," Oxford Handbook of Genocide Studies, ed. Donald Bloxham and A. Dirk Moses (Oxford: Oxford UP, 2010), 638-60; Tor A. Benjaminsen, "Does Supply-Induced Scarcity Drive Violent Conflicts in the African Sahel?" Journal of Peace Research 45,6 (2008): 819-36; Idean Salehyan, "From Climate Change to Conflict? No Consensus Yet," Journal of Peace Research 45,3 (2008): 315-26.

5. Marcia Esparza, Henry Huttenbach, and Daniel Feierstein, eds., State Violence and Genocide in Latin America: The Cold War Years (New York: Routledge, 2009).

6. For histories of the field, see Donald Bloxham and A. Dirk Moses, "Editors' Introduction: Changing Themes in the Study of Genocide," in Bloxham and Moses, Oxford Handbook of Genocide Studies, 1-18; A. Dirk Moses, "Introduction: The Field of Genocide Studies," in Genocide, ed. A. Dirk Moses (London: Routledge, 2010), 1-23; Samuel Totten and Steven Jacobs, Pioneers of Genocide Studies (Rutgers, NJ: Transaction, 2002).

7. I explore this more extensively in "The Political Science of Genocide: Outlines of an Emerging Research Agenda," Perspectives on Politics (forthcoming Jun 2012). Martin Shaw explores the problem of definitional inconsistencies in What is Genocide? (Cambridge: Polity Press, 2007).

8. For an overview, see Maureen Hiebert, "Theorizing Destruction: Reflections on the State of Comparative Genocide Theory," Genocide Studies and Prevention 3,3 (2008): 309-33, http://dx.doi.org/10.3138/ gsp.3.3.309.

9. Charles Tilly, The Politics of Collective Violence (Cambridge: Cambridge UP, 2003), 20.

10. The specific relationship between war and genocide is still debated, however. See Martin Shaw, War \& Genocide (Cambridge: Polity Press, 2003); Christopher R. Browning, The Origins of the Final Solution: The Evolution of Nazi Jewish Policy, September 1939-March 1942 (Lincoln, NE: U of Nebraska P, 2004); Scott Straus, The Order of Genocide: Race, Power and War in Rwanda (Ithaca, NY: Cornell UP, 2006); Donald Bloxham, "The Armenian Genocide of 1915-1916: Cumulative Radicalization and the Development of a Destruction Policy," Past and Present 181 (Nov 2003): 141-92; Manus Midlarsky, "The Demographics of Genocide: Refugees and Territorial Loss in the Mass Murder of European Jewry," Journal of Peace Research 42 (Jul 2005): 375-91.

11. For examples of such approaches, see Jacques Semelin, Purify and Destroy: The Political Uses of Massacres and Genocide (New York: Columbia UP, 2007); Eric D. Weitz, A Century of Genocide: Utopias of Race and Nation (Princeton, NJ: Princeton UP, 2003).

12. Adam Jones lists over twenty scholarly definitions of genocide as well as many more cognate terms used in the field, in Genocide: An Introduction, 2nd ed. (New York: Routledge, 2010),16-20, 26-9.

13. Formally put, it lacks variation on the dependent variable. On this methodological problem more generally, see David Collier and James Mahoney, "Insights and Pitfalls: Selection Bias in Qualitative Research," World Politics 49 (1996): 56-91; Alexander L. George and Andrew Bennet, Case Studies and Theory Development in the Social Sciences (Cambridge, MA: MIT Press, 2005). An exception is Michael Mann, The Dark Side of Democracy: Explaining Ethnic Cleansing (Cambridge: Cambridge UP, 2005), 474-501.

14. State repression can include a wide variety of practices, such as limitations on formal civil and political liberties, language restrictions or suppression, spying, counterterrorism, counterinsurgency, "preventive" detention, targeted or mass killings, and systematic extermination.

15. Erica Chenoweth and Adria Lawrence, eds., Rethinking Violence: State and Non-State Actors (Cambridge, MA: MIT Press, 2010); Charles Tilly, From Mobilization to Revolution (New York: Longman, 1978) and Tilly, Collective Violence; Mark Lichbach, "Deterrence or Escalation? The Puzzle of Aggregate Studies of Repression and Dissent," Journal of Conflict Resolution 31 (1987): 266-97; Steven Poe and Neal Tate, "Repression of Human Rights to Personal Integrity in the 1980s: A Global Analysis," American Political Science Review 88 (1994): 853-900; Christian Davenport, "State Repression and Political Order" Annual Review of Political Science 10 (2007): 1-10.

16. Ervin Staub's important study, The Roots of Evil, examined these and many other dynamics in impressive detail, though he is less clear on whether all of the factors he presents are necessary for genocide to occur (or perhaps only some of them in particular combinations). Without an examination of nongenocidal violent cases, the theory's explanatory power is left undefined. See Staub, Roots of Evil: The Origins of Genocide and Other Group Violence (Cambridge: Cambridge UP, 1989).

17. Stathis Kalyvas, The Logic of Violence in Civil War (Cambridge: Cambridge UP, 2006); Elisabeth Wood, Collective Action and Civil War in El Salvador (Cambridge: Cambridge UP, 2003); Charles Tilly and Sidney Tarrow, Contentious Politics (New York: Paradigm, 2006).

18. For exceptions, see Mann, Dark Side of Democracy; Manus Midlarsky, The Killing Trap: Genocide in the Twentieth Century (Cambridge: Cambridge UP, 2005); Christian Gerlach, Extremely Violent Societies: Mass Violence in the Twentieth Century World (Cambridge: Cambridge UP, 2010). 
19. Vahakn Dadrian, The History of the Armenian Genocide: Ethnic Conflict from the Balkans to Anatolia to the Caucasus (Providence, RI: Berghahn Books, 1997); Vahakn Dadrian, Warrant for Genocide: Key Elements of Turko-Armenian Conflict (New Brunswick, NJ: Transaction, 1999); Leo Kuper, Genocide: Its Political Uses in the Twentieth Century (New Haven, CT: Yale UP, 1983); Richard G. Hovannisian, "Etiology and Sequelae of the Armenian Genocide," in Genocide: Conceptual and Historical Dimensions, ed. George Andreopolous (Philadelphia, PA: U of Pennsylvania P, 1994), 111-40; Irving Louis Horowitz, Taking Lives: Genocide and State Power, 5th ed., rev. (New Brunswick, NJ: Transaction, 2002); Rudolph Rummel, Death by Government (New Brunswick, NJ: Transaction, 1997); Hannah Arendt, The Origins of Totalitarianism (New York: Harcourt, 1951).

20. Barbara Harff, "No Lessons Learned From the Holocaust? Assessing Risks of Genocide and Political Mass Murder Since 1955," American Political Science Review 97,1 (Feb 2003): 57-73; Benjamin Valentino, Final Solutions: Mass Killing and Genocide in the Twentieth Century (Ithaca, NY: Cornell UP, 2004).

21. Mann, Dark Side of Democracy.

22. Alexander Laban Hinton, Why Did They Kill? Cambodia in the Shadow of Genocide (Los Angeles: U of California P, 2005); Ben Kiernan, The Pol Pot Regime: Race, Power and Genocide in Cambodia under the Khmer Rouge, 1975-1979 (New Haven, CT: Yale UP, 1996); Donald Bloxham, The Final Solution: A Genocide (Oxford: Oxford UP, 2009).

23. On the national-level approach, see James Fearon and David Laitin, "Ethnicity, Insurgency and Civil War," American Political Science Review 97,1 (2003): 75-90. On microanalytical advances in civil war analysis, see Halvard Buhaug and Jan Ketil Rod, "Local Determinants of African Civil Wars, 19702001," Political Geography 25,3 (2006): 315-35; Lars-Erik Cederman and Luc Girardin, "Beyond Fractionalization: Mapping Ethnicity onto Nationalist Insurgencies," American Political Science Review 101,1 (2007): 173-85; Kalyvas, Logic of Violence in Civil War; Wood, Collective Action and Civil War; Tilly and Tarrow, Contentious Politics; Patricio Justino, "Poverty and Violent Conflict: A Micro-Level Perspective on the Causes and Duration of Warfare," Journal of Peace Research 56,3 (2009): 315-33; Ashutosh Varshney, Ethnic Conflict and Civic Life: Hindus and Muslims in India (New Haven, CT: Yale UP, 2002).

24. Hinton, Why Do They Kill?; Paul Brass, Theft of an Idol: Text and Context in the Representation of Collective Violence (Princeton, NJ: Princeton UP, 1997).

25. Though see James A. Tyner, War, Violence and Population: Making the Body Count (New York: Guilford, 2009); Nils Weidmann, "Geography as Motivation and Opportunity: Group Concentration and Ethnic Conflict," Journal of Conflict Resolution 53,4 (2009): 526-43.

26. Rummel, Death by Government, 1.

27. Matthew Krain, "State-Sponsored Mass Murder: The Onset and Severity of Genocides and Politicides," Journal of Conflict Resolution 41,3 (1997): 331-60. On measuring state power, see Cullen Hendrix, "Measuring State Capacity: Theoretical and Empirical Implications for the Study of Civil Conflict," Journal of Peace Research 47,3 (2010): 273-85.

28. Uğur Ümit Üngör, "When Persecution Bleeds into Mass Murder: The Processive Nature of Genocide," Genocide Studies and Prevention 1,2 (2006): 173-96, http://dx.doi.org/10.3138/0252-6L27-67M7-7320; Hinton, Why Do They Kill?; Straus, Order of Genocide; Lee Ann Fujii, Killing Neighbors: Webs of Violence in Rwanda (Ithaca, NY: Cornell UP, 2009); Philip Verwimp, "Machetes and Firearms: The Organization of Massacres in Rwanda," Journal of Peace Research 43,1 (2006): 5-22; Ravi Bhavnani and David Backer, "Localized Ethnic Conflict and Genocide: Accounting for Differences in Rwanda and Burundi," Journal of Conflict Resolution 44,3 (2000): 283-306.

29. Christian Gerlach, "Extremely Violent Societies: An Alternative to the Concept of Genocide," Journal of Genocide Research 4,4 (2006): 455-72.

30. Straus, "Second Generation," 499.

31. Charles Tilly, Big Structures, Large Processes, Huge Comparisons (New York: Russell Sage Foundation, 1984). 